\title{
Effect of Different Sources of Phosphorus on Soil Enzymes Activity in Groundnut (Arachis hypogaea L)
}

\author{
M. Swetha Kumari*, P. Chandrasekhar Rao, G. Padmaja, V. Ramulu and J.D. Saritha
}

Department of Soil science and Agricultural Chemistry, College of Agriculture, Pjtsau, Hyd-30, India

*Corresponding author

\section{A B S T R A C T}

\section{Keywords}

Different sources of phosphorus,

Enzymes activity, Groundnut

Article Info

Accepted:

04 June 2018

Available Online:

10 July 2018
Field experiment was conducted in the college form college of agriculture Rajendranagar during the 2015 kharif season to investigate the effect of nano-fertilizer on mineral status of groundnut crop grown under rainfed conditions. The treatments were as follows: The treatments comprised of T1-Control(no fertilizers were applied), T2- RDF $\mathrm{N}, \mathrm{P}_{2} \mathrm{O}_{5}$, $\mathrm{K}_{2} \mathrm{O} @ 20: 40: 50 \mathrm{~kg} \mathrm{ha}^{-1}, \mathrm{~T} 3-\mathrm{RDF} \mathrm{NK}+$ Soil application of Nanophos@65 $\mathrm{kgha}^{-1}$ at sowing, T4-RDF NK +Soil application of biophos@65 kg ha ${ }^{-1}$ at the time of sowing and T5- RDF $\mathrm{NK}+$ foliar application of $\mathrm{P}$ as $1 \%$ DAP, T6- RDF NK+foliar application of nanophos@1ml 1 $\mathrm{l}^{-1}$, T7- RDF NK +foliar application of nanophos@2ml 1-1, T8-RDF NK +foliar application of biophos@2 $\mathrm{ml} \mathrm{l}^{-1}$,T9-RDF NK+ foliar application of nanophos@4ml $\mathrm{l}^{-1}$ foliar treatments were given at flowering and pod formation stages.

\section{Introduction}

Phosphorus plays an important role in Agricultural production. Agriculture is the major user of phosphorus resources $(\mathrm{P})$, accounting for $80-90 \%$ of the world demand for P. Increasing population, growing favourites towards diets meals and rising demands for bio-energy crops will increase the future demand for $\mathrm{P}$ fertilizers. However, application of $\mathrm{P}$ fertilizers aggravates eutrophication problem in surface waters. Thus, numerous regulations, best managements practices and remediation technology have been proposed to reduce $\mathrm{P}$ fertilizer application to prevent the applied $\mathrm{P}$ from entering water bodies. However, few work on attempting to solve the eutrophication problem via the modifications of the chemical properties of fertilizers (e.g., reducing the fertilizer mobility in the soil or decreasing bioavailability of nutrients to the algae. The nano-scaling of a fertilizer is considered a mitigation method to get an effective fertilizer as well as reduces the risk of eutrophication (Tarafdar et al, 2012). To evaluate the influence of Nano and Bio phosphorus practices on soil biological health, the three enzymes which are released by microorganisms during the decomposition and which have a bearing on soil nutrient transformations are chosen for the study. The 
effect of different treatments was evaluated in terms of soil enzymatic activity viz., urease, dehydrogenase, acid and alkaline phosphatase activity at vegetative, flowering and harvest stages.

Urease is unique among soil enzymes and greatly affects the fate and performance of important fertilizer like urea. Soil urease catalyses the hydrolysis of urea to carbondioxide and $\mathrm{NH}_{4}^{+}$, a form assimilable by plants.

Dehydrogenases are generally present in upper layer of soils. Dehydrogenases, as respiratory chain enzymes, play the major role in the energy production of organisms. They oxidize organic compounds by transferring two hydrogen atoms. Dehydrogenases are essential components of the enzyme systems of microorganisms. Dehydrogenase activity can, therefore, be used as an indicator of biological redox systems and as a measure of microbial activity in soil, which in turn influences the nutrient availability to plants (Chaithanya, 2003).

Soil phosphomonoesterases i. e. acid and alkaline phosphatases are the most important in plant nutrition; these are involved in mineralization of organically bound phosphorus to inorganic phosphorus compounds in soil.

A recent approach, green nanotechnology has emerged which includes a range of processes that reduce or eliminate toxic substances to restore environment. Microorganisms like fungi and bacteria having naturally bestowed property of reducing and oxidizing metal ions nanoparticles (Jain et al, 1990).With this background the present investigation entitled effect of different sources of phosphorus on soil enzymes activity in groundnut (Arachis hypogaea. L).

\section{Materials and Methods}

A field experiment was conducted on a sandy loam soil (Alfisol) at college Farm, College of Agriculture, Rajendranagar, Hyderabad during kharif season of 2015 with a view to study the effect of Bio and Nano Phosphorus on soil enzymatic activity viz., urease, dehydrogenase, acid and alkaline phosphatase activity at vegetative, flowering and harvest stages. Experiment was laid out in randomized block design with three replications and 9 treatments. The initial soil was sandy loam in texture. The physico-chemical properties revealed that the soil was slightly alkaline $(8.08 \mathrm{pH})$ in reaction, non-saline $(0.74 \mathrm{dS} / \mathrm{m})$ in nature and low in organic carbon $(0.49 \%)$. Dehydrogenase activity in soil ( $\mu \mathrm{g}$ TPF produced/g soil/24 h) was assayed at vegetative, flowering and final harvest by the colorimetric determination of 2, 3, 5-triphenyl formazan produced from the reduction of 2,3 , 5-triphenyl tetrazolium chloride as described by Casida et al., (1964). Urease activity was assayed by quantifying the rate of release of $\mathrm{NH}^{4+}$ from the hydrolysis of urea. The acid and alkaline phosphatase activity was assayed by quantifying the amount of pnitrophenol released and expressed as $\mu \mathrm{g}$ of pnitrophenol released/g soil/h as described byTabatabai and Bremner (1969). Nitrogen (256 kg N/ha), medium in available.

\section{Results and Discussion}

To evaluate the influence of Bio and Nano phosphorus application on soil biological health, the three enzymes which were released by microorganisms during the decomposition and which had a bearing on soil nutrient transformations were chosen for the study. The effect of different treatments was evaluated in terms of soil enzymatic activity viz., urease, dehydrogenase, acid and alkaline phosphatase activity at vegetative, flowering and harvest stages. The data pertaining to soil 
enzymatic activities at different growth stages of groundnut are given below.

\section{Urease activity in soil}

Effect of different sources of phosphorus on the activity of soil urease $\left(\mu \mathrm{g} \mathrm{NH}_{4}{ }^{+}\right.$released $\mathrm{g}^{-1}$ soil $2 \mathrm{hr}^{-1}$ ) at different growth stages are depicted in figure 1 . The urease activity showed an increasing trend with the age of the crop. It increased from flowering stage to harvesting stage, exhibited highest activity at pod formation stage and there after the activity decreased at maturity. Similarly, Ramalakshmi (2011) also reported highest urease activities at panicle initiation stage in long term nutrient management practices on rice. Similar results were reported by Senthilkumar (2000) at different growth stages of groundnut. Significant differences were observed in urease activity among all the treatments at all stages.

In this study it was observed that the enzyme activity was found to increase with foliar and soil application of biophos at different growth stages of crop growth.

At flowering the highest urease activity was observed in the treatment receiving RDF NK +soil application of biophos @65 kg ha ${ }^{-1}$ $\left(72.50 \mu \mathrm{g} \mathrm{NH}{ }^{+}\right.$released $\mathrm{g}^{-1}$ soil $2 \mathrm{hr}^{-1}$ ) followed by RDF $\mathrm{NK}$ + foliar application of biophos@ $@ \mathrm{ml} \mathrm{l}^{-1}$ (69.66 $\mu \mathrm{g} \mathrm{NH}_{4}^{+}$released g ${ }^{-1}$ soil $2 \mathrm{hr}^{-1}$ ) these two treatments on par with each other. Followed by $\mathrm{RDF} \mathrm{NK}+$ foliar

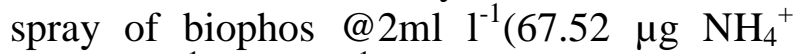
released $\mathrm{g}^{-1}$ soil $2 \mathrm{hr}^{-1}$ ), followed by RDF NK+ foliar application of nanophos @ $2 \mathrm{ml}^{-1}$ (66.00 $\mu \mathrm{g} \mathrm{NH}_{4}^{+}$released $\mathrm{g}^{-1}$ soil $2 \mathrm{hr}^{-1}$ ) and foliar spray of nanophos@ @ $1 \mathrm{ml} \mathrm{l}^{-1}\left(62.50 \mu \mathrm{g} \mathrm{NH}_{4}^{+}\right.$ released $\mathrm{g}^{-1}$ soil $2 \mathrm{hr}^{-1}$ ). The lowest urease activity was observed in control $(25.33 \mu \mathrm{g}$ $\mathrm{NH}_{4}{ }^{+}$released $\mathrm{g}^{-1}$ soil $2 \mathrm{hr}^{-1}$ ) which was followed by Foliar spray of $1 \% \mathrm{P}$ as DAP ( $48.67 \mu \mathrm{g} \mathrm{NH}_{4}{ }^{+}$released g ${ }^{-1}$ soil $2 \mathrm{hr}^{-1}$ ).
At pod formation stage there was a maximum increase in urease activity and the treatment receiving soil application of biophos @ $65 \mathrm{~kg}$ $\mathrm{ha}^{-1}$ recorded the highest activity $(95.00 \mu \mathrm{g}$ $\mathrm{NH}_{4}{ }^{+}$released $\mathrm{g}^{-1}$ soil $2 \mathrm{hr}^{-1}$ ) followed by foliar application of biophos @ $4 \mathrm{ml} \mathrm{l}^{-1}$ and $2 \mathrm{ml} \mathrm{l}^{-1}\left(82.00\right.$ and $78.82 \mu \mathrm{g} \mathrm{NH}_{4}{ }^{+}$released $\mathrm{g}^{-1}$ soil $\left.2 \mathrm{hr}^{-1}\right)$. Followed by the treatments foliar spray of nanophos@2 $\mathrm{ml} \mathrm{l}^{-1}\left(75.67 \mu \mathrm{g} \mathrm{\textrm {NH } _ { 4 }}{ }^{+}\right.$ released $\mathrm{g}^{-1}$ soil $2 \mathrm{hr}^{-1}$ ) and foliar applications of nanophos @ $1 \mathrm{ml} \mathrm{l} 1^{-1} \quad\left(73.58 \mu \mathrm{g} \quad \mathrm{NH}_{4}^{+}\right.$ released $\mathrm{g}^{-1}$ soil $2 \mathrm{hr}^{-1}$ ) were on par with each other. Lowest activity was seen in case of control $\left(28.83 \mu \mathrm{g} \mathrm{NH}_{4}^{+}\right.$released $\mathrm{g}^{-1}$ soil 2 $\left.\mathrm{hr}^{-1}\right)$.

At harvest there was a much decrease in urease activity among all the treatments and the highest value was seen in soil application of biophos @65 kg ha ${ }^{-1}\left(67.16 \mu \mathrm{g} \mathrm{NH}_{4}^{+}\right.$ released $\mathrm{g}^{-1}$ soil $\left.2 \mathrm{hr}^{-1}\right)$. These treatments were followed foliar application of biophos@ $4 \mathrm{ml} \mathrm{l}^{-}$ ${ }^{1}\left(60.32 \mu \mathrm{g} \mathrm{NH}_{4}{ }^{+}\right.$released $\mathrm{g}^{-1}$ soil $\left.2 \mathrm{hr}^{-1}\right)$, these was followed by foliar application of biophos @ $2 \mathrm{ml} \mathrm{l}^{-1}\left(57 \mu \mathrm{g} \mathrm{NH}_{4}{ }^{+}\right.$released $\mathrm{g}^{-1}$ soil $\left.2 \mathrm{hr}^{-1}\right)$, foliar spray of nano phos@ $2 \mathrm{ml}^{-1}(52.53 \mu \mathrm{g}$ $\mathrm{NH}_{4}{ }^{+}$released $\mathrm{g}^{-1}$ soil $\left.2 \mathrm{hr}^{-1}\right)$ and foliar spray of nanophos $1 \mathrm{ml} \mathrm{l}^{-1}\left(51.16 \mu \mathrm{g} \mathrm{NH}_{4}{ }^{+}\right.$released $\mathrm{g}^{-1}$ soil $2 \mathrm{hr}^{-1}$ ) on par with each other. The lowest was recorded in control (18.83 $\mu \mathrm{g}$ $\mathrm{NH}_{4}{ }^{+}$released $\mathrm{g}^{-1}$ soil $2 \mathrm{hr}^{-1}$ ). The results of the present study indicate that urease activity increased continuously and reached maximum at pod formation stage and decreased at harvest.

\section{Acid and alkaline phosphatase activity in soil}

The effect of different sources of phosphorus on the activity of acid and alkaline phosphatase ( $\mu \mathrm{g}$ of $p$-nitrophenol $\mathrm{g}^{-1}$ soil $\mathrm{hr}^{-1}$ ) is in figure 2 .

Phosphatases are broad groups of enzymes that are capable of catalyzing hydrolysis of 
esters and anhydrides of phosphoric acid. In soil ecosystems, these enzymes are believed to play critical roles in P cycles (Speir and Ross, 1978) as evidence shows that they are correlated to $\mathrm{P}$ stress and plant growth. Phosphatase is an enzyme present in all the microorganisms and increase in its activity is mainly due to increase in bacterial biomass. Temporal sequence in activity of this enzyme may be due to the differential production rates which may be influenced by the physiological age of different groups of microorganisms present in the soil (Srinivaset al., 2003).

\section{Acid phosphatase activity}

The acid phosphatase activity showed slight increasing trend with the age of the crop from flowering to pod formation stage. It exhibited highest activity at pod formation stage and there after the activity decreased at maturity.

At flowering stage the highest acid phosphatase activity was observed in the treatment receiving RDF NK + Soil application of biophos @ $65 \mathrm{~kg} \mathrm{ha}^{-1}$ at sowing (38.87 $\mu \mathrm{g}$ of $p$-nitrophenol $\mathrm{g}^{-1}$ soil $\mathrm{hr}^{-1}$ ) followed by RDF NK + soil application of nanophos@65 kg ha ${ }^{-1}$ at sowing (35.32 $\mu \mathrm{g}$ of p-nitrophenol g-1 soil hr ${ }^{-1}$ ). The treatment RDF $\mathrm{NK}+$ Foliar application of biophos@ $4 \mathrm{ml} \mathrm{1}^{-1}$ and $2 \mathrm{ml}^{-1}(32.81$ and $30.72 \mu \mathrm{g}$ of $p$ nitrophenol $\mathrm{g}^{-1}$ soil $\mathrm{hr}^{-1}$ ) followed by RDF @ 20:40:50 kg ha ${ }^{-1}(29.15 \mu \mathrm{g}$ of $p$-nitrophenol $\mathrm{g}^{-1}$ soil $\left.\mathrm{hr}^{-1}\right)$. The treatment RDF NK + Foliar application of $1 \% \mathrm{P}$ as DAP $(24.75 \mu \mathrm{g}$ of $\mathrm{p}$ nitrophenol $\mathrm{g}^{-1}$ soil $\mathrm{hr}^{-1}$ ) which was on par with RDF+ NK Foliar application of nanophos@1ml ${ }^{-1}$ (22.82 $\mu \mathrm{g}$ of $p$-nitrophenol $\mathrm{g}^{-1}$ soil $\left.\mathrm{hr}^{-1}\right)$. The lowest acid phosphatase activity was observed in control $(16.10 \mu \mathrm{g}$ of p-nitrophenol $\mathrm{g}^{-1}$ soil $\mathrm{hr}^{-1}$ ).

At pod formation stage there was a maximum increase in acid phosphatase activity and the treatment receiving recorded the highest activity RDF NK + soil application of biophos @ $65 \mathrm{~kg} \mathrm{ha}^{-1}$ at sowing $(51.00 \mu \mathrm{g}$ of $\mathrm{p}$ nitrophenol $\mathrm{g}^{-1}$ soil $\mathrm{hr}^{-1}$ ) followed by RDF NK + Soil application of nanophos as impregnated granules@65 kg ha ${ }^{-1}$ at sowing $(49.35 \mu \mathrm{g}$ of $\mathrm{p}$-nitrophenol $\mathrm{g}^{-1}$ soil hr$\left.{ }^{-1}\right)$. The lowest activity was recorded in control $(31.50 \mu \mathrm{g}$ of $p$ nitrophenol $\mathrm{g}^{-1}$ soil $\mathrm{hr}^{-1}$ ).

There was a gradual decrease seen in acid phosphatase activity at harvesting sage and the treatment receiving $\mathrm{RDF} \mathrm{NK}+$ soil application of biophos @ $65 \mathrm{~kg} \mathrm{ha}^{-1}$ at sowing (39.74 $\mu \mathrm{g}$ of $\mathrm{p}$-nitrophenol $\mathrm{g}^{-1}$ soil $\mathrm{hr}^{-1}$ ) followed by RDF NK +soil application of nanophos @65kg ha $\mathrm{ka}^{-1}(36.17 \mu \mathrm{g}$ of pnitrophenol $\mathrm{g}^{-1}$ soil $\left.\mathrm{hr}^{-1}\right)$. RDF NK + Foliar application of biophos @ 4ml 1-1 $(34.25 \mu \mathrm{g}$ of p-nitrophenol $\mathrm{g}^{-1}$ soil $\mathrm{hr}^{-1}$ ) and RDF NK+ foliar application of biophos @ $2 \mathrm{ml} \mathrm{l}^{-1}(32.50$ $\mu \mathrm{g}$ of $p$-nitrophenolg ${ }^{-1}$ soil $\left.\mathrm{hr}^{-1}\right)$. The treatments RDF NK + foliar application of nanophos @ $2 \mathrm{ml} \mathrm{l}^{-1} \quad(32.21 \mu \mathrm{g}$ of $\mathrm{p}$ nitrophenol $\mathrm{g}^{-1}$ soil hr-1) and RDF NK + Foliar application nanophos @ $1 \mathrm{ml} \mathrm{l}^{-1}(30.25 \mu \mathrm{g}$ of p-nitrophenol $\mathrm{g}^{-1}$ soil $\mathrm{hr}^{-1}$ ) was on par with each other. The lowest acid phosphatase activity was seen in control $(22.53 \mu \mathrm{g}$ of $p$ nitrophenol $\mathrm{g}^{-1}$ soil $\mathrm{hr}^{-1}$ ).

\section{Alkaline phosphatase activity}

From data in figure 3 it was observed that the alkaline phosphatase activity showed an increase with the age of the crop and exhibited highest activity at pod formation stage and there after the activity decreased at maturity.

At flowering stage the highest alkaline phosphatase activity was observed in the treatment receiving RDF NK + soil application of biophos@65kg ha $\mathrm{kg}^{-1}(64.40 \mu \mathrm{g}$ of $p$ nitrophenol $\mathrm{g}^{-1}$ soil $\mathrm{hr}^{-1}$ ) which was on par with the RDF NK + soil application of nanophos@65kg ha ${ }^{-1}(59.63 \mu \mathrm{g}$ of $p$ nitrophenol $\mathrm{g}^{-1}$ soil $\mathrm{hr}^{-1}$ ) which was followed 
by RDF NK+ foliar application of biophos@4 $4 \mathrm{ml} \mathrm{l}^{-1}\left(49.50 \mu \mathrm{g}\right.$ of $p$-nitrophenol $\mathrm{g}^{-1}$ soil $\mathrm{hr}^{-1}$ ) foliar application of biophos@ $2 \mathrm{ml}$ $\mathrm{l}^{-1}\left(47.62 \mu \mathrm{g}\right.$ of $p$-nitrophenol $\mathrm{g}^{-1}$ soil hr$\left.{ }^{-1}\right)$ on par with Recommended dose of NPK @ 20: 40: $50 \mathrm{~kg} \mathrm{ha}^{-1}\left(46.59 \mu \mathrm{g}\right.$ of $p$-nitrophenol g ${ }^{-1}$ soil $\left.\mathrm{hr}^{-1}\right)$. The lowest acid phosphatase activity was observed in control $(33.40 \mu \mathrm{g}$ of $p$ nitrophenol g ${ }^{-1}$ soil hr-1 ${ }^{-1}$.

At pod formation stage there was a maximum increase in alkaline phosphatase activity and the treatment receiving $\mathrm{RDF} \mathrm{NK}+$ Soil application of biophos@65 kg ha ${ }^{-1}$ at sowing recorded the highest activity $(75.20 \mu \mathrm{g}$ of $p$ nitrophenol $\mathrm{g}^{-1}$ soil $\mathrm{hr}^{-1}$ ). This treatment was followed by RDF NK + Soil application of nanophos as impregnated granules @ $65 \mathrm{~kg}$ $\mathrm{ha}^{-1}$ at sowing $\left(64.31 \mu \mathrm{g}\right.$ of $p$-nitrophenol g $\mathrm{g}^{-1}$ soil $\left.\mathrm{hr}^{-1}\right)$. The treatments RDF NK + Foliar application of bio phos@4ml ${ }^{-1}$ (62.81 $\mu \mathrm{g}$ of $p$-nitrophenol $\mathrm{g}^{-1}$ soil $\mathrm{hr}^{-1}$ ) and RDF NK + Foliar application of biophos @ 2 $\mathrm{ml} \mathrm{l}^{-1}(60.21$ $\mu \mathrm{g}$ of p-nitrophenol $\mathrm{g}^{-1}$ soil $\mathrm{hr}^{-1}$ ) were on par with each other. The lowest activity was recorded in control $(46.31 \mu \mathrm{g}$ of $p$-nitrophenol $\mathrm{g}^{-1}$ soil $\left.\mathrm{hr}^{-1}\right)$.

There was a gradual decrease seen in alkaline phosphatase activity at harvesting stage and the treatment receiving $\mathrm{RDF} \mathrm{NK}+$ soil application of biophos @ $65 \mathrm{~kg} \mathrm{ha}^{-1}$ at sowing recorded the highest activity $60.32 \mu \mathrm{g}$ of $p$ nitrophenol $\mathrm{g}^{-1}$ soil $\mathrm{hr}^{-1}$ ) followed by RDF NK + soil application of nanophos @ $65 \mathrm{~kg} \mathrm{ha}^{-1}$ (55.01 $\mu \mathrm{g}$ of p-nitrophenol $\mathrm{g}^{-1}$ soil $\mathrm{hr}^{-1}$ ), RDF NK + Foliar application of biophos @ $4 \mathrm{ml} \mathrm{l}^{-1}$ (47.25 $\mu \mathrm{g}$ of p-nitrophenol $\mathrm{g}^{-1}$ soil $\left.\mathrm{hr}^{-1}\right)$.

The treatments RDF NK + Foliar application of biophos @ $2 \mathrm{ml} \mathrm{l}^{-1}$ (45.37 $\mu \mathrm{g}$ of $p$ nitrophenol $\mathrm{g}^{-1}$ soil $\mathrm{hr}^{-1}$ ) and treatments RDF NPK @ 20:40:50kg ha ${ }^{-1}(42.50 \mu \mathrm{g}$ of $p$ nitrophenol $\mathrm{g}^{-1}$ soil $\mathrm{hr}^{-1}$ ) was on par with each other. The lowest acid phosphatase activity was seen in control $(31.00 \mu \mathrm{g}$ of $p$-nitrophenol $\mathrm{g}^{-1}$ soil hr-1 $)$.

\section{Dehydrogenase activity in soil}

The dehydrogenase activity is commonly used as an indicator of biological activity in soils (Burns, 1978). Dehydrogenase enzyme is known to oxidize soil organic matter by transferring protons and electrons from substrates to acceptors. These processes are part of respiration pathways of soil microorganisms and closely related to the type of soil. The activity of dehydrogenase enzyme in the soil systems is very important as it gives indications of the potential of the soil to support biochemical processes which are essential for maintaining soil fertility (Joachim et al., 2008).

The data on effect of different sources and methods of application of phosphorus on activity of dehydrogenase $(\mu \mathrm{g}$ TPF produced $\mathrm{g}^{-1}$ soil $\mathrm{d}^{-1}$ ) is presented in and depicted in Figure 4.

The dehydrogenase activity showed an increasing trend with the age of the crop from flowering to pod formation stage and exhibited highest activity at pod formation stage and there after the activity decreased at maturity.

Rai and Yadav (2011) stated that the increased microbial population was responsible for sharp increase in dehydrogenase activity of soil and also reported that activities of urease and dehydrogenase were significantly and positively correlated with organic carbon content in the soil.

At flowering stage the highest dehydrogenase activity was observed in the treatment receiving soil application of biophos @65 kg $\mathrm{ha}^{-1}$ recorded the highest activity $(83.83 \mu \mathrm{g}$ TPF produced $\mathrm{g}^{-1}$ soil $\mathrm{d}^{-1}$ ). This treatment was followed by foliar spray of biophos@ $4 \mathrm{ml} \mathrm{l}^{-1}$ (70.43 $\mu \mathrm{g}$ TPF produced $\mathrm{g}^{-1}$ soil $\mathrm{d}^{-1}$ ). The lowest dehydrogenase activity was recorded in control (25.29 $\mu \mathrm{g}$ TPF produced $\mathrm{g}^{-1}$ soil $\left.\mathrm{d}^{-1}\right)$. 
At pod formation stage there was a maximum increase in dehydrogenase activity and the treatment receiving soil application of biophos @ 65 kg ha ${ }^{-1}$ recorded the highest activity (94.24 $\mu \mathrm{g}$ TPF produced $\mathrm{g}^{-1}$ soil $\mathrm{d}^{-1}$ ). This treatment was followed by Foliar spray of biophos@4 ml 1 ${ }^{-1}\left(75.89 \mu \mathrm{g}\right.$ TPF produced $\mathrm{g}^{-1}$ soil $\left.\mathrm{d}^{-1}\right)$. This was followed by RDF NK+ foliar application of biophos @2 $\mathrm{ml} \mathrm{l}^{-1}$ (72.91 $\mu$ g TPF produced $\mathrm{g}^{-1}$ soil $\mathrm{d}^{-1}$ ) which was on par with each other. The lowest dehydrogenase activity was recorded in control $\left(36.21 \mu \mathrm{g}\right.$ TPF produced $\mathrm{g}^{-1}$ soil $\left.\mathrm{d}^{-1}\right)$.

There was a gradual decrease in dehydrogenase activity at harvesting stage and the treatment receiving $\mathrm{RDF} \mathrm{NK}+$ soil application of biophos @ $65 \mathrm{~kg} \mathrm{ha}^{-1}$ recorded the highest activity (66.46 $\mu \mathrm{g}$ TPF produced $\mathrm{g}^{-1}$ soil $\mathrm{d}^{-1}$ ) followed by foliar spray of biophos @ $4 \mathrm{ml}^{-1}\left(56.05 \mu \mathrm{g}\right.$ TPF produced $\mathrm{g}^{-1}$ soil $\left.\mathrm{d}^{-1}\right)$ and foliar application of biophos@2 $\mathrm{ml} \mathrm{l}^{-1}$ $\left(53.57 \mu \mathrm{g}\right.$ TPF produced $\mathrm{g}^{-1}$ soil $\left.\mathrm{d}^{-1}\right)$. Followed by $\mathrm{RDF} \mathrm{NK}+$ foliar application of nanophos @ $2 \mathrm{ml} \mathrm{l}^{-1}\left(49.10 \mu \mathrm{g}\right.$ TPF produced $\mathrm{g}^{-1}$ soil $\left.\mathrm{d}^{-1}\right)$ was on par with each other. The lowest dehydrogenase activity was seen in control (19.34 $\mu \mathrm{g}$ TPF produced $\mathrm{g}^{-1}$ soil $\mathrm{d}^{-1}$ ).

The treatment receiving the soil application of phosphorus has led to an increased activity of enzymes. Addition of phosphorus to soil may influence microbial proliferation and enzyme activity possibly leading to an increase in rates of biochemical process in the soil environment.

Tarafdar et al., (2014) reported a significant improvement in enzyme activities of acid phosphatase $(76.9 \%)$, alkaline phosphatase $(61.7 \%)$ and dehydrogenase $(21 \%)$ over control in 6 weeks old pearl millet plants due to application of phosphorus nanofertilizers.

Extracellular secretion of enzymes offers the advantage to obtain pure, mono disperse nanoparticles, associated with downstream processing. The microbial synthesis of $\mathrm{P}$ nanoparticles involves an enzyme mediated process which is present in extracellular secrets and another protein act as capping protein play role in the further encapsulation of P nanoparticles and increase stability. Such biologically synthesized, very tiny functional nanoparticles are economically chief, relatively stable, easy downstream processing and environmentally safe as they are encapsulated by mother protein which is water soluble (Rathor et al., 2015). The ability of isolated bacteria for enhanced secretion of phytase along with phosphatases may help to enhance more plant available $\mathrm{P}$ though the hydrolysis of organic esters (Tarafdar and Marschner, 1994) or mobilizing tri- calcium phosphate. The importance of soil microorganisms for increasing the availability of $\mathrm{P}$ from phytate through the provision phytase activity has similarly been suggested by Richardson et al., (2001). Besides the cleavage of C-O-P ester bond by microbial phosphatase or phytase, the microorganisms may also produce different organic acids (Jones and Sreenivasa, 1993), which may possibly help in greater release of $\mathrm{P}$.

Microbial activity is a key factor in the soil organic P cycle (Tarafdar and Gharu, 2006) and affects the transformation of inorganic $\mathrm{P}$. In our study, maximum enzyme release was observed after 5-8 weeks (60 days) of growth. Higher enzyme release by the organisms indicated the potential of soil to affect the biochemical transformations necessary for the maintenance of soil fertility (Rao et al., 1990). A higher biomass accumulation would be associated with greater release of phytase and phosphatases and the mobilization of more unavailable P. Enhanced secretion of phytase by rhizosphere microorganisms (Tarafdar and Marschner, 1994) may contribute to $\mathrm{P}$ acquisition through the hydrolysis of organic esters in the rhizosphere. 
Fig.1 Effect of different sources and methods of application of phosphorus on urease activity in soil $\left(\mu \mathrm{g}\right.$ of $\mathrm{NH}_{4}{ }^{+}$released $\mathrm{g} \mathrm{soil}{ }^{-1} 2 \mathrm{~h}^{-1}$ ) at different growth stages in groundnut

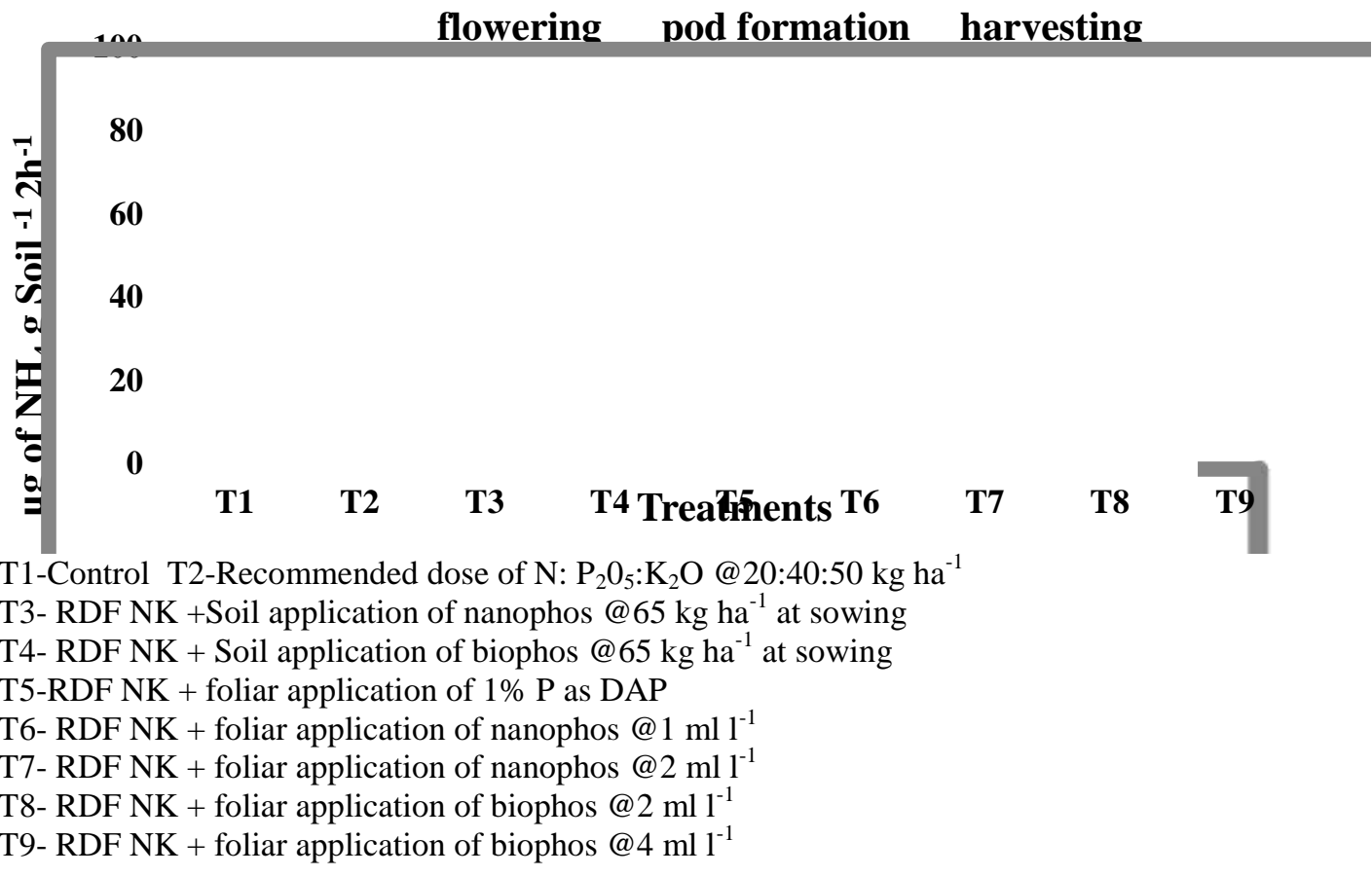

Fig.2 Effect of different sources and methods of application of phosphorus on acid phosphatase activity in soil ( $\mu \mathrm{g}$ of $\mathrm{P}$ - Nitrophenol $\mathrm{g}^{-1}$ soil $\mathrm{h}^{-1}$ ) at different growth stages in groundnut

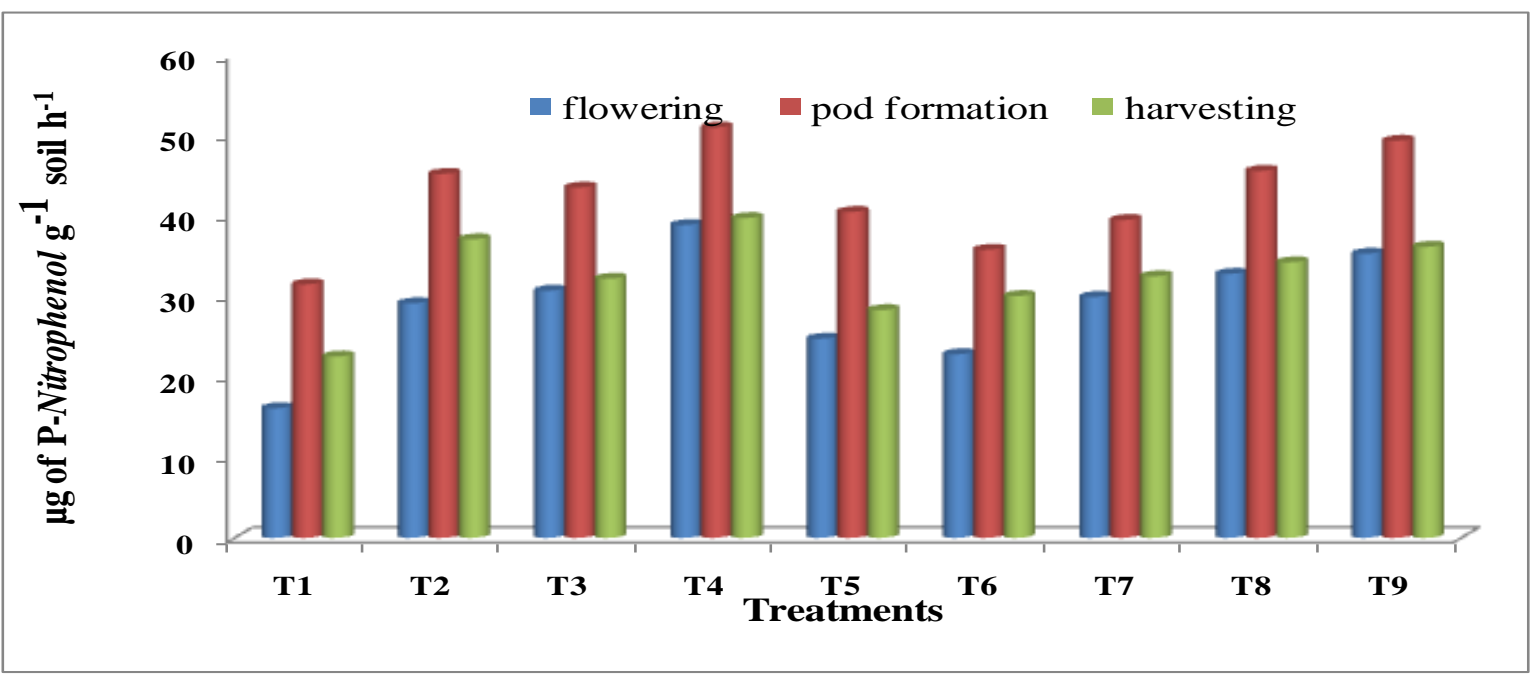

T1-Control T2-Recommended dose of N: $\mathrm{P}_{2} 0_{5}: \mathrm{K}_{2} \mathrm{O} @ 20: 40: 50 \mathrm{~kg} \mathrm{ha}^{-1}$

T3- RDF NK +Soil application of nanophos @ $65 \mathrm{~kg} \mathrm{ha}^{-1}$ at sowing

T4- RDF NK + Soil application of biophos@65 kg ha-1 at sowing

T5-RDF NK + foliar application of $1 \% \mathrm{P}$ as DAP

T6- RDF NK + foliar application of nanophos @ $1 \mathrm{ml} \mathrm{l}^{-1}$

T7- RDF NK + foliar application of nanophos @ $2 \mathrm{ml} \mathrm{l}^{-1}$

T8- RDF NK + foliar application of biophos @ $2 \mathrm{ml} \mathrm{l}^{-1}$

T9- RDF NK + foliar application of biophos @ $4 \mathrm{ml} \mathrm{l}^{-1}$ 
Fig.3 Effect of different sources and methods of application of phosphorus on alkaline phosphatase activity in soil ( $\mu \mathrm{g}$ of P-Nitrophenol $\mathrm{g}^{-1}$ soil $^{-1}$ ) at different growth stages in groundnut

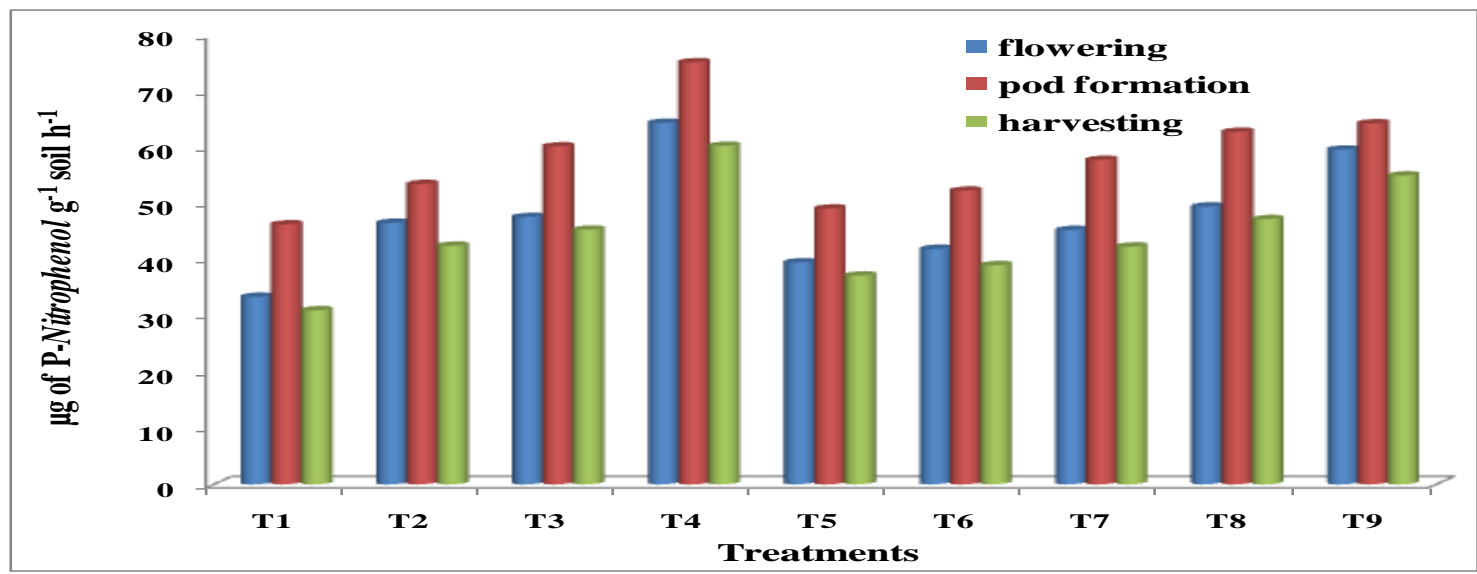

T1-Control T2-Recommended dose of $\mathrm{N}: \mathrm{P}_{2} \mathrm{O}_{5}: \mathrm{K}_{2} \mathrm{O} @ 20: 40: 50 \mathrm{~kg} \mathrm{ha}^{-1}$

T3- RDF NK +Soil application of nanophos @ $65 \mathrm{~kg} \mathrm{ha}^{-1}$ at sowing

T4- RDF NK + Soil application of biophos @ $65 \mathrm{~kg} \mathrm{ha}^{-1}$ at sowing

T5-RDF NK + foliar application of $1 \% \mathrm{P}$ as DAP

T6- RDF NK + foliar application of nanophos @ $1 \mathrm{ml} \mathrm{l}^{-1}$

T7- RDF NK + foliar application of nanophos @ $2 \mathrm{ml}^{-1}$

T8- RDF NK + foliar application of biophos @ $2 \mathrm{ml} \mathrm{l}^{-1}$

T9- RDF NK + foliar application of biophos @ $4 \mathrm{ml} \mathrm{l}^{-1}$

Fig 4.Effect of different sources and methods of application of phosphorus on dehydrogenase activity in soil ( $\mu \mathrm{g}$ of TPF $\mathrm{g} \mathrm{soil}^{-1} \mathrm{Day}^{-1}$ ) at different growth stages in groundnut

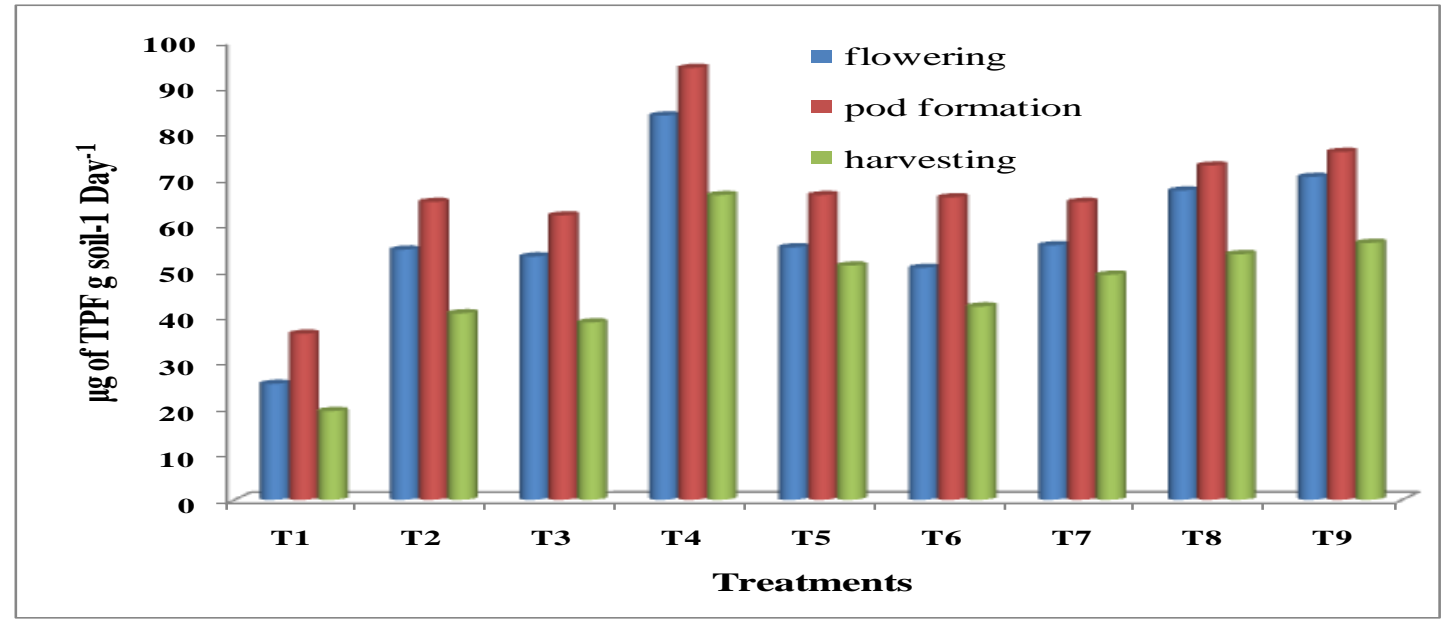

T1-Control T2-Recommended dose of $\mathrm{N}: \mathrm{P}_{2} 0_{5}: \mathrm{K}_{2} \mathrm{O} @ 20: 40: 50 \mathrm{~kg} \mathrm{ha}^{-1}$

T3- RDF NK +Soil application of nanophos @ $65 \mathrm{~kg} \mathrm{ha}^{-1}$ at sowing

T4- RDF NK + Soil application of biophos @ $65 \mathrm{~kg} \mathrm{ha}^{-1}$ at sowing

T5-RDF NK + foliar application of $1 \% \mathrm{P}$ as DAP

T6- RDF NK + foliar application of nanophos @ $1 \mathrm{ml} \mathrm{l}^{-1}$

T7- RDF NK + foliar application of nanophos @ $2 \mathrm{ml} \mathrm{l}^{-1}$

T8- RDF NK + foliar application of biophos @2 $\mathrm{ml} \mathrm{l}^{-1}$

T9- RDF NK + foliar application of biophos @ $4 \mathrm{ml} \mathrm{l}^{-1}$ 


\section{References}

Burns, R.G. 1978. Enzyme activity in soils, some theoretical and practical modifications. Soil Enzymes. (Burns RG, Ed.). Academic press, London.295-340.

Cassida, L. E., Klein, D. A and Santaro, J. 1964. Soil dehydrogenase activity. Soil Science. 98: 371-76.

Chaitanaya Devi, M., Ramavatharam, N., M.V.S and Reddy, K.S. 2013. Effect of inorganic fertilizers and organic manures on growth, yield and uptake of nutrients by groundnut (Arachis hypogaea L.) Journal of Oilseeds Research. 20 (1): 126-128.

Jain, R.C., Nema, D.P., Khandhe, R and Thakur. 1990.Effect of phosphorus and potassium on yield, nutrient uptake, protein and oil content of groundnut. Indian Journal of Agricultural Science. 60: 559-561.

Joachima, H.J.R., Makoil and Patrick, A.N. 2008.Selected soil enzymes, examples of their potential roles in the eco system. African Journal of Biotechnology.7 (3): 181 - 191.

Jones, P and Sreenivasa, M.N. 1993. Response of sunflower to the inoculation of VA mycorrhiza and or phosphate solubilising bacteria in black clayey soil. Journal of Oilseeds Research.10 (1): 86-92.

Rai, T.N and Yadav, J. 2011. Influence of inorganic and organic nutrient sources on soil enzyme activities. Journal of the Indian society of Soil Science. 59(1): $54-59$.

Ramalakshmi, Ch. S. 2011.Vermicomposting for effective waste management and its evaluation under INM rice - pulse cropping system. M.Sc. (Ag.) Thesis. Acharya N. G. Ranga Agricultural University, Hyderabad.
Rao, A.V., Bala, K and Tarafdar, J.C. 1990. Dehydrogenase and phosphatase activities in soil as influenced by the growth of arid-land crops. Indian Journal of Agricultural Science. 115:221-225.

Rathor, I., Sen, M., Dhariwal, A.G and Tarafdar, J.C. 2015. An efficient Bm strain JC-T13 producing nanophosphorus particles from phytin and solubilizing phosphates. International Journal of Current Engineering and Technology.5(6).

Richardson, A.E., Hadobas, P.A., Hayes, J.E., Hara, C.P and Simpson, R.J. 2001.Utilization of phosphorus by pasture plants supplied with myoinositol hexaphosphate is enhanced by the presence of soil microorganisms. Plant and Soil, 229: 47-56.

Senthilkumar, S. 2000. Integrated plant nutrient supply system in hybrid rice. M.Sc. (Ag.)thesis.Acharya N.G. Ranga Agriculutral University, Rajendranagar, Hyderabad.

Speir, T.W and Ross, D.J. 1978. Soil phosphatase and sulphatase. In: Burns RG (Ed) Soil enzymes. Academic Press. London, UK, pp: 197-250.

Srinivas, D., Raman, S and Rao, P. C. 2003.Effect of organic manures and activities of certain soil enzymes under submerged conditions. 40(1\&2): 14-17.

Tabatabai, M.A and Bremner, J.M. 1969.Use of p-nitrophenyl phosphate for assay of soil phosphatase activity. Soil Biology and Biochemistry. 1: 301-307.

Tarafdar, J. C., Raliya, R and Rathore, I. 2012. Microbial synthesis of phosphorus nanoparticles from Tricalcium phosphate using Aspergillus tubingensis TFR-5.Journal of Bionanoscience. 6: 84-89.

Tarafdar, J.C and Gharu, A. 2006.Mobilization of organic and 
poorly soluble phosphates by Chaetomium globosum. Applied Soil Ecology. 32: 273-283.

Tarafdar, J.C and Marschner, H.1994. Phosphatase activity in the rhizosphere and hyphosphere of VA mycorrhizal wheat supplied with inorganic and organic phosphorus. Soil Biology and Biochemistry. 26(3):387-395.

\section{How to cite this article:}

Swetha Kumari, M., P. Chandrasekhar Rao, G. Padmaja, V. Ramulu and Saritha, J.D. 2018. Effect of Different Sources of Phosphorus on Soil Enzymes Activity in Groundnut (Arachis hypogaea. L). Int.J.Curr.Microbiol.App.Sci. 7(07): 340-349. doi: https://doi.org/10.20546/ijcmas.2018.707.041 